\title{
Effectiveness of group counseling in smoking cessation program amongst adolescent smokers in Malaysia
}

\author{
Rohani Ismail,, Syed Mohamed Aljunid Syed Aljunid, ${ }^{1}$ Khalib A. Latip, ${ }^{3}$ Sharifa E. W. Puteh ${ }^{3}$ \\ ${ }^{1}$ School of Health Sciences, University Science of Malaysia \\ ${ }^{2}$ United Nations University - International Institute for Global Health, Kuala Lumpur Malaysia \\ ${ }^{3}$ Department of Community Health, Universiti Kebangsaan Malaysia
}

\begin{abstract}
Abstrak
Tujuan: mengevaluasi efektiftasi konseling kelompok untuk menghentikan merokok di antara murid sekolah menengah.

Metode: Penelittian dilakukan diatara murid sekolah menegah di dua kabupaten Negeri Selangor Malaysia pada bulan Juli 2005 sampai Agustus 2006. Setelah dilakukan skrining, 346 murid dibagi secara acak menjadi dua grup. Grup pertama yang diberi konseling (IG) sebanyak 158 orang dan grup ke dua yang tidak diberi konseling (NIG) sebanyak 188 orang. Konseling teratur terstruktur dilakukan selama empat bulan, sedangkan grup yang tidak diberikan konseling hanya mendapatkan program penghentian merokok sesuai program di sekolah yang berangkutan. Pada kedua grup, pengetahuan, sikap terhadap merokok, dan kadar berhenti merokok diukur sebelum intervensi, pada bulan intervensi ke 4, 8, dan 12.

Hasil: Murid pada IG secara signifikan mempunyai pengetahuan dibandingkan dengan NIG selama intervensi masing-masing: 24,29+7,97 vs 23.58+8,44 (pada kunjngan pertama); 29,10+8,52 vs 24.09+8.69 pada kunjungan ke dua; 26,59+8,26 vs 22.08+8.04 pada kunjungan ke tiga; dan 25,54+8,34 vs 21,26+9,60 pada kunjungan ke empat. Sedangkangkan skor sikap tidak berbeda signifikan antara kedua grup. Setelah intervensi, kadar berhenti merokok secara signifikan lebih tinggi di antara grup IF dibandingkan grup NIG (45\% vs 32\%; P=0.013).
\end{abstract}

Kesimpulan: Konseling berkelompok sangat efektif untuk meningkatkan pengetahuan dan penghentian merokok, akan tetapi tidak terhadap sikap merokok. (Med J Indones 2010; 19:273-9)

\begin{abstract}
Aim: To assess the effectiveness of groups counseling for smoking cessation among secondary school students.

Methods: This study was conducted among secondary school students in two districts in Selangor Malaysia, during July 2005 until August 2006. Upon screening, 346 students were randomly assigned into intervention group (IG) $(n=158)$ and non intervention group (NIG) $(n=188)$. IG underwent structured group counseling regularly for four months, while no group counseling was given to the NIG but subjected to the regular smoking cessation activities organized by their respective schools. Knowledge and attitude towards smoking and quit rate were measured in both groups before intervention, and at 4, 8, and 12 months after intervention.

Results: Revealed that students in IG had significantly higher knowledge scores than those in NIG during follow-up visits $(24.29 \pm 7.97$ vs $23.58+8.44$ on the first visit), $(29.10 \pm 8.52$ vs $24.09 \pm 8.69$ on the second visit) $(26.59 \pm 8.26$ vs $22.08 \pm 8.04$ on the third visit) and (25.54 \pm 8.34 vs $21.26+9.60$ on the fourth visit). Attitude scores were not significantly different in both groups. Quit rate at four months after intervention was significantly higher in IG as compared to the NIG $(45 \% ; 71 / 158$ vs $32 \% ; 60 / 188)(P=0.013)$.
\end{abstract}

Conclusion: Group counseling is very effective in improving the respondents' knowledge and quite rate, but not their attitudes toward smoking. (Med J Indones 2010; 19:273-9)

Key words: attitude, group counseling, intervention, knowledge, smoking cessation

Tobacco is the single most important cause of preventable deaths where smokers have two to three times higher death rates than non-smokers at all ages. ${ }^{1}$ Smoking is often initiated during adolescence and prone to continue into adulthood. ${ }^{2}$ Increasing the likelihood of long-term adverse health outcomes linked to cancer, heart and lung disease, and adverse effects on reproduction and the fetus. ${ }^{3}$
Although the consequences from smoking were well documented, smoking rates among adolescents still remain high in developing countries, including Malaysia. ${ }^{4}$ The national prevalence of current smoking among adolescents shows an increasing trend from the age 13 to 17 years old: for 13 years old (3.5\%), 14 years old $(6.0 \%), 15$ years old $(8.7 \%), 16$ years old $(12.0 \%)$ and 17 years old $(15.5 \%)^{5}$. Prevalence increases with 
age and the most common age of starting smoking was 13-14 years old. ${ }^{6}$ Hence it is logical for the smoking cessation program to be implemented at the earliest age to prevent the adolescents from turning into regular smokers and become heavy smoker at the older age.

Intervention must take into account the adolescents' readiness to change and the fact remains that the smokers themselves will determine whether or not to change their behavior. The provision of adequate support for smokers who are motivated to quit is essential, to help smokers not only initiate the process of quitting but also to continue to follow up throughout the process in order to maintain successful abstinence.

Group behavioral interventions are recognized as one of the most effective methods of smoking cessation. ${ }^{8}$ Furthermore, concerns about the safety of medication use for individual under age 18 and cost of pharmacotherapy, cognitive-behavioral interventions have been suggested as a better option with this age group. ${ }^{9} 10$ Realizing the importance of theses issues, group counseling smoking cessation package was developed to assist school counselors in facilitating secondary school students to stop smoking.

The aim of this study was to implement and to assess the group counseling smoking cessation package and to measure the effectiveness of the intervention through three indicators: smokers' knowledge, attitude and quit rate.

\section{METHODS}

\section{Study areas}

Selangor is one of 12 states in Peninsular Malaysia with nine districts. Hulu Langat and Gombak are two purposively selected districts based on the similar ethnics' distribution and high prevalence of smoking among secondary school students. ${ }^{11}$ There were 35 secondary schools in Hulu Langat district and 31 schools in Gombak district. A total of 14 schools in Hulu Langat and 10 schools in Gombak district were randomly selected in the initial screening process involving all 14 years old secondary school students

\section{Participants}

The screening process was conducted among 6,827 respondents in 24 schools in these two districts. All the students were given questionnaires for screening process which were included of socio demographics characteristic, smoking profile, nicotine addiction as well as stages of stop smoking. Upon screening, a total of 346 adolescents (301 males and 45 females) met the inclusion criteria of this study which were: (1) self-profess to smoking at least one day within the last 30 days (confirmed by carbon monoxide analyzer); (2) Intention to stop smoking (in contemplation, preparation and motivation stage). All participants must obtain initial formal written parental consent to participate in the program.

\section{Smoking cessation package}

The Smoking Cessation Package (SCP) was developed by experts from various fields such as counselors and psychologists, health promotion experts, educators and clinical psychiatrist. These experts were selected from the Ministry of Health, Ministry of Education, National Poison Centre and Universiti Kebangsaan Malaysia. Four existing counseling modules used as references in the development of the package: (1) Life Skill Training: ${ }^{12}$ (2) Health Education Package ${ }^{13}$ (3) Module CERAH, Ministry of Health. ${ }^{14}$

These four modules contents were reviewed and pre tested before implementations in school. The package consists of 10 counseling sessions: (1) 1st Module Preparation to Stop Smoking ( $1^{\text {st }}, 2^{\text {nd }}$ session); (2) $2^{\text {nd }}$ Module - Decision Making ( $3^{\text {rd }}, 4^{\text {th }}, 5^{\text {th }}$ session); (3) $3^{\text {rd }}$ Module - Managing Withdrawal Symptom $\left(6^{\text {th }}, 7^{\text {th }}\right.$ session); (4) $4^{\text {th }}$ Module - Remaining Cessation Status $\left(8^{\text {th }}, 9^{\text {th }}, 10^{\text {th }}\right.$ session $)$.

These programs used various strategies in groups counseling process which include discussions, handouts and posters, video presentation, puzzles, games and homework. Students were given information on bad consequences of smoking as well as guidelines to stop smoking. In this learning process no punishment implemented in contrast rewarded such as camping activities and certificate were given for successful stop smokers.

\section{Study groups}

The Intervention Group (IG) consisted of 158 students and the Non Intervention Group (NIG) consisted of 188 students. IG and NIG were in different schools. The students were assigned into IG and NIG using single blind approach. The IG received ten sessions of 'Stop Smoking Module' in groups counseling settings. They 
does not received regular smoking cessation program. Counseling for students in the IG was managed by school counselors. The students, in groups of 6 to 10 people, received counseling from the school counselors. The NIG did not receive any SCP counseling but were subjected to the regular smoking cessation activities organized by their respective schools.

\section{Program implementation}

The intervention group (IG) met once a week for ten weeks and each meeting lasted about $1 \frac{1}{2}$ hours to 2 hours. Some groups met before or during school academic sessions depending on accessibility of students to attend the counseling sessions. All meetings were held in counseling rooms to ascertain participants' confidentiality and privacy.

\section{Recruitment and training of facilitators}

A total of 17 counselors were recruited to implement the SCP module. Criteria used in choosing appropriate counselors were had at least one year working experience as counselor, received formal training in counseling and psychology and agreed to participate in the study. The counselors attended a two-day training workshop provided by our research team. Guidelines to conduct the SCP modules were given to the counselors. More specifically, they received instructions on program implementation and role plays during training sessions. Simulations exercises were conduct in order to expose counselors to deal with the real situation during interventions. In addition to the module guidelines for each session, the counselors also received information booklets on stop smoking, posters, compact discs on harmful effects of smoking and diary where by students will list their daily activities that induced them to smoke. The diary will be used by the students on daily basis for a period of four month starting from the dates they agree to stop smoking.

\section{Measures}

Students completed a self administered questionnaire four times point during the study: (i) before the start of the cessation intervention counseling session. (ii) at 4 month after the completion group counseling intervention. (iii) at 8 -month which is after 4 month of without intervention, to assess maintenance behavior of change in short term period. (iv) at 12 month which is after 8 months of without intervention to assess maintenance behavior in long term. The whole schedule of the implementation of intervention was designed to take into account of the time constraint due to school break and other curriculum activities.

\section{Baseline data}

In baseline data, chi squared test and student t-test was performed to measure the similarity of socio demography characteristics between two groups. The categorical data (sex, race, initiation age of smoking, intention to stop smoking, number of cigarettes per day past 30 days and nicotine addiction) were based on chi squared test where as continues data (mean pocket money per day) was based on student t-test.

\section{Knowledge}

Analysis of two ways repeated measure ANOVA (Spanova) was performed in order to assess changes in knowledge for intervention (IG) and non intervention group (NIG) over time ( $1^{\text {st }}$ visit (baseline), $2^{\text {nd }}$ visit (4 months post baseline), $3^{\text {rd }}$ visit ( 8 months post baseline, $4^{\text {th }}$ visit (12 months post baseline).

The questionnaire comprised of 50 items organized into 4 sections: i) harmful effects of smoking (22 items), ii) benefits of stop smoking (6 items questions), iii) chemical contents in cigarettes (10 questions) and iv) general questions (4 items). For the first, second and third section, the answers scored between 0 and 1 (false and don't know $=0$, true $=1$ for positive item and vice versa for negative item). The last section comprised of 4 general questions. First question is on "definition of passive smoker" and the answers were scored (true $=1$; false and not sure $=0$ ). For second question is about "harmful of side stream smoke" and the answers were scored (Definitely yes $=1$; probably yes, probably no and definitely no $=0$ ). Third question refers to "smoking under age 18 " and the answers were scored (National law $=1$; school regulation, custom, police regulation and no prohibition at all $=0$ ). Fourth question refers "religions view on smoking" and the answers were scored (strong prohibition $=1$; Less prohibition, No prohibition, Allowed and Not encourage $=0$ ). The maximum and minimum score were 50 and 0 respectively. The reliability coefficient (Chronbach's alpha) for this instrument was 0.86 . 


\section{Attitude}

Analysis of two ways repeated measure ANOVA (Spanova) was performed to asses changes in attitude for IG and NIG over time ( baseline $-1^{\text {st }}$ visit), $2^{\text {nd }}$ visit (4 month post baseline), $3^{\text {rd }}$ visit ( 8 month post baseline, $4^{\text {th }}$ visit (12 month post baseline).

The questionnaires comprised of 20 items (2 sections) regarding attitude towards smoking. The first section consists of 11 questions which were validated by the counselors based on their opinion regarding the actual questions measuring attitude towards smoking. Each question was scaled from 1 to 5 (very high measured to very low measured). Minimum score was 11 and maximum score was 55. A total of 11 counselors returned the questionnaires with the maximum score of 45 and minimum score of 31 . Each question was weighted based on the score measured by the counselors. Score of above 44 was weighted 1.5 for good attitude whilst those less than 44 were weighted 1.0 for good attitude. Maximum score for this section was 12 and minimum score was 0 . In the second section consists of 9 questions were scored as 1 and 0 [(agree $=1$, disagree and not sure $=0$ ) for positive questions] and [(disagree $=1$, agree and not sure $=0)$ for negative question]. Maximum score was 9 and minimum score was 0 . Overall score for attitude in both section maximum was $21(12+$ 9 ) and minimum score was 0 . Higher score indicated more positive attitude. The reliability coefficient (Chronbach's alpha) for this instrument was 0.56 .

\section{Urine cotinine}

Urine samples were analysed for cotinine by Gas Chromatography Mass Spectrometry (GCMS). The final cotinine product were divided into 5 categories; i) $<5$ $\mathrm{ng} / \mathrm{ML}=$ no expose, ii) 5-10.99 ng/ML = less expose, iii) 11-29.99 $\mathrm{ng} / \mathrm{ML}=$ moderate expose, iv) 30-99.99 $\mathrm{ng} / \mathrm{ML}=$ high expose, $\mathrm{v})>100 \mathrm{ng} / \mathrm{ML}=$ smoking

\section{Carbon monoxide}

Exhale carbon monoxide (CO) was measured using portable carbon monoxide analyzer. Respondents had to hold breath for 20 minutes before blowing into mouthpiece connected to a detector. Results were grouped into 4 categories i) $0-6 \mathrm{ppm}=$ non smoker, ii) 7-10ppm $=$ light smoker, iii) 11$20=$ moderate smoker, iv) $>20=$ heavy smoker

\section{Nicotine addiction}

Nicotine addiction was measured using 6 questions. Scores were divided into 3 categories; i) Low ( $0-3$ score), ii) Moderate (4- 6 score), iii) High (7-10). Minimum and maximum score is 0 and 10 respectively.

\section{Quit rates}

Quit rates were measured at 4, 8 and 12 months post baseline, using a question "are you smoking past seven days", with dichotomous answer of yes and no. The responses were verified by urine cotinine $(<99.99 \mathrm{ng} /$ $\mathrm{ML})$ and exhaled carbon monoxide test $(<6 \mathrm{ppm})$.

\section{RESULTS}

\section{Baseline characteristics}

Table 1 showed baseline data of between intervention and non intervention group. There is no significant difference for all the parameters which meant both groups were comparable.

Table 1. Baseline several characteristics of intervention and non intervention group

\begin{tabular}{|c|c|c|c|}
\hline & $\begin{array}{l}\text { Intervention } \\
\quad(\mathrm{n}=158)\end{array}$ & $\begin{array}{c}\text { Non intervention } \\
\quad(\mathrm{n}=188)\end{array}$ & \\
\hline & Frequency $(\%)$ & Frequency (\%) & \\
\hline Gender & & & 0.075 \\
\hline Male & $143(90.5)$ & $\begin{array}{c}158(84.0) \\
30(16.0)\end{array}$ & \\
\hline Female & $15(9.5)$ & & \\
\hline Race & & & 0.425 \\
\hline Malay & $153(96.8)$ & $179(95.2)$ & \\
\hline Chinese & $2(1.3)$ & $1(0.5)$ & \\
\hline Indian & $3(1.9)$ & $6(3.2)$ & \\
\hline $\begin{array}{l}\text { Mean pocket money per } \\
\text { day }\left(\mathrm{RM}^{*}\right)\end{array}$ & $2.80 \pm 1.65)$ & $3.00 \pm 2.38)$ & 0.442 \\
\hline Initiation age of smoking & & & 0.222 \\
\hline $7-9$ years & $12(7.6)$ & $19(10.2)$ & \\
\hline $10-11$ years & $25(15.8)$ & $34(18.2)$ & \\
\hline $12-13$ years & $91(57.6)$ & $87(46.5)$ & \\
\hline $14-15$ years & $30(19.0)$ & $47(25.1)$ & \\
\hline Intention to stop smoking & & & 0.807 \\
\hline Contemplation & $66(41.8)$ & $73(38.8)$ & \\
\hline Preparation & $37(23.4)$ & $49(26.1)$ & \\
\hline Action & $55(34.8)$ & $66(35.1)$ & \\
\hline $\begin{array}{l}\text { Number of cigarettes per } \\
\text { day past } 30 \text { days }\end{array}$ & & & 0.156 \\
\hline 1 stick & $60(50.6)$ & $114(61.0)$ & \\
\hline 2-5 sticks & 63 (39.9) & 59 (31.6) & \\
\hline$>6$ sticks & $15(9.5)$ & $14(7.5)$ & \\
\hline Nicotine addiction & & & 0.494 \\
\hline Less addicted & $138(87.3)$ & $161(85.6)$ & \\
\hline Moderate addicted & $18(11.4)$ & $21(11.2)$ & \\
\hline High addicted & $2(1.3)$ & $6(3.2)$ & \\
\hline
\end{tabular}

*RM=Malaysian Ringgit 


\section{Knowledge}

The results indicated that there was significant effect of time on knowledge scores $(\mathrm{p}<0.001)$. Knowledge of participants in IG increased from the first visit to the second visit, and then decreased during third visit and fourth visit. For the NIG, knowledge slightly increased from the first visit to the second visit, then decreased during the third visit and fourth visit.

The similar analysis also indicated a significant effect of knowledge between IG and NIG with $\mathrm{p}<0.001$ (IG gain more knowledge as compared with NIG for each visits). (Refer table 2)

Table 2. Mean score of knowledge based on two way repeated measure analysis

\begin{tabular}{lcc}
\hline & \multicolumn{2}{c}{ Mean score } \\
\cline { 2 - 3 } & $\begin{array}{c}\text { Intervention } \\
(\mathrm{n}=134)\end{array}$ & $\begin{array}{c}\text { Non intervention } \\
(\mathrm{n}=158)\end{array}$ \\
\hline $\begin{array}{l}\text { Baseline } \\
\left(1^{\text {st }} \text { visit }\right)\end{array}$ & $24.29 \pm 7.97$ & $23.58 \pm 8.44$ \\
4 month post baseline (2 ${ }^{\text {nd }}$ visit) & $29.10 \pm 8.52$ & $24.09 \pm 8.69$ \\
8 month post baseline (3 ${ }^{\text {rd }}$ visit $)$ & $26.59 \pm 8.26$ & $22.08 \pm 8.04$ \\
12 month post baseline (4 ${ }^{\text {th }}$ visit $)$ & $25.54 \pm 8.34$ & $21.26 \pm 9.60$ \\
\hline
\end{tabular}

Significant difference (ANOVA test) between time visits $(\mathrm{p}<0.001)$; Significant difference (ANOVA test) between IG and NIG $(\mathrm{p}<0.001)$

\section{Attitude}

There was a significant effect of time in both IG and NIG with $p<0.001$. Attitude for the IG increased from the first visit to the second visit, then decrease during the third and fourth visits respectively. The similar trend found for the NIG. There were no significant effects on attitude between IG and NIG and no significant interactions for the both groups. (Refer table 3)

Table 3. Mean score of attitude based on two way repeated measure analysis

\begin{tabular}{lcc}
\hline & \multicolumn{2}{c}{ Mean score } \\
\cline { 2 - 3 } & $\begin{array}{c}\text { Intervention } \\
(\mathrm{n}=134)\end{array}$ & $\begin{array}{c}\text { Non intervention } \\
(\mathrm{n}=158)\end{array}$ \\
\hline $\begin{array}{l}\text { Baseline } \\
\left(1^{\text {st }} \text { visit }\right)\end{array}$ & $9.05 \pm 2.08$ & $8.95 \pm 2.11$ \\
$\begin{array}{l}4 \text { month post baseline } \\
\left(2^{\text {nd }} \text { visit }\right)\end{array}$ & $14.09 \pm 3.30$ & $14.04 \pm 3.33$ \\
8 month post baseline & $13.05 \pm 3.00$ & $12.39 \pm 3.21$ \\
$\begin{array}{l}\left.3^{\text {rd }} \text { visit }\right) \\
12 \text { month post baseline } \\
\left(4^{\text {th }} \text { visit }\right)\end{array}$ & $12.85 \pm 3.03$ & $12.22 \pm 4.05$ \\
\hline
\end{tabular}

Significant difference between time visits $(\mathrm{p}<0.001)$

No significant difference between IG and NIG

\section{Quit rate}

The quit rate at four months after intervention was significantly higher in the IG $(45 \% ; 71 / 158)$ as compared to the NIG $(32 \% ; 60 / 188) \quad(p=0.013)$. However at 8 and 12 months post intervention, the quit rates were not significantly different between both groups. Quit rates 8 months were IG-21\%; NIG- $24 \%$ and at 12 months IG- $18 \%$, NIG- $26 \%$ respectively with no significant difference between groups $(p=0.499)$ and (0.087) (Refer table 4).

Table 4. Quit rates of intervention and nonintervention group

\begin{tabular}{lccc}
\hline & $\begin{array}{c}\text { Intervention } \\
(\mathrm{n}=158)\end{array}$ & $\begin{array}{c}\text { Nonintervention } \\
(\mathrm{n}=188)\end{array}$ & $\mathrm{p}$ \\
\cline { 2 - 3 } & Frequency $(\%)$ & Frequency $(\%)$ & 0.013 \\
\hline $\begin{array}{l}4 \text { month post baseline } \\
\left(2^{\text {nd }} \text { visit }\right)\end{array}$ & $71(44.9)$ & $60(31.9)$ & 0.499 \\
8 month post baseline & $33(20.9)$ & $45(23.9)$ & 0.087 \\
$\begin{array}{l}\left(3^{\text {rd }} \text { visit }\right) \\
12 \text { month post baseline } \\
\left(4^{\text {th }} \text { visit }\right)\end{array}$ & $29(18.4)$ & $49(26.1)$ & \\
\hline
\end{tabular}

p based on $\chi 2$ tests

\section{DISCUSSION}

The increasing level of knowledge among IG impressively exhibits the awareness towards the counseling program introduced. Conversely declining of smoking cessation awareness after intervention proved that the injection of knowledge at school level is mooted to be introduced and continuously extended in longer term. These findings strongly proved that counseling programs would be able to contribute to the enhancement of knowledge towards smoking cessation among the participants as compared to NIG group. Small group counseling initiated more valuable outcome from the counseling session, as compared to the big group that usually associated with a limited effect. One of the reinforcing values in a group process, were when individuals were able to discuss their perceptions of themselves and received immediate feedback on how the other members of the group perceived them. ${ }^{15}$

Meanwhile, attitude of secondary school students presented with a small changes in intervention as well as non intervention group. Attitude change require long period of intervention. In a process of measuring attitude, is a little trickier than measuring knowledge because how people feel about something is a little harder to pin down in black and white. ${ }^{16}$ 
The present study revealed that both knowledge and attitude immediately increased after the intervention program. It is crucial for the students to have continuous intervention in order to ensure the knowledge and attitude scores remain high. The implication of this intervention program saw generally exhibit the capability of increasing students' knowledge on smoking and attitude. However, there are not much different for attitude among participants. These finding supported by research where by the intervention program was successful in improving smoking knowledge, but not the attitudes. ${ }^{17}$ The most successful attitude intervention should focus on module approaches which were comprised of discussion, modeling behavior, role play, extended practice, and public commitment not to smoke. ${ }^{18}$

In terms of quit rate, study showed that quit rate among participants in IG was significantly higher than NIG. The intervention was pertinently effective at 4 months but at 8 and 12 months without counseling program, there was no significant difference between IG and NIG. Quit rate after 8 and 12 month follow up showed decreasing rate in intervention group. This observation is comparable with that already reported in the literature. ${ }^{19}$ An active follow up program is crucial to ensure the program sustained in long term period. About $50 \%$ to $80 \%$ of the smoker who have smoke therapy program will relapse after follow up without the program. ${ }^{13}$ Relapse occurs due to development of withdrawal symptom such as irritability, agitation difficulty in concentrating, frustration, nervousness and tension. Another recommendation is applying 'booster' intervention program to have more lasting effects. The booster intervention program such as self motivation should be injected among quit smokers as well as among non stop smokers until they giving up in order increasing the quit rate and sustaining successful intervention.

In conclusion, group counseling is very effective in improving the respondents' knowledge and quit rate but not their attitudes toward smoking. In the process of changing attitude we need ample time with more effort and cooperation from everybody involved in the program. The module is effectives in encouraging respondents to quit smoking only in the short term. As a result the duration of intervention should be extended to enhance its impact on knowledge and attitude of smokers simultaneously sustain the quit rate among adolescents in the long term.

\section{Acknowledgments}

We gratefully acknowledge experts from National University of Malaysia, Ministry of Health, Ministry of
Education and National Poison Centre for their valuable information in developing module on stop smoking. We are also grateful to Pn. Che Nin and Pn. Syazwani from National Poison Centre for their help with analyzing urine cotinine. Also special thanks to Mr.Raja Azman and Mr. Fadzli Ahmad from Education District Officer Hulu Langat and Gombak respectively also counselors in Hulu Langat and Gombak districts for their excellent help in implementing the interventions, the school's administration and students for their cooperation in this study.

The study has been funded by grants FF-168-2005 from the Universiti Kebangsaan Malaysia, Research Network and Malaysia Council for Tobacco Control.

\section{REFERENCES}

1. Lum MSW. Smoking: health information series. Kuala Lumpur: MSWLUM; 2004.

2. Conrad KM, Flay BR, Hill D. Why children start smoking cigarette: predictors of onset. Br J Addiction. 1992; 87:171124.

3. Slovic P. Smoking: risk, perception and policy. USA: Sage Publications; 2001.

4. Mackay J, Eriksen M, Shafey O. The Tobacco Atlas. $2^{\text {nd }}$ ed.Atlanta, GA: Am Cancer Soc. 2006.

5. Ministry of Health Malaysia. Smoking among adolescents (Age 13-<18 years old) 2009. Cited 2009 October 10. http:// www.nih.gov.my/NHMS/abstracts_14.html.

6. Lee LK, Paul CYC, Kam CW, Hagmohni K. Smoking among secondary school students in Negeri Sembilan, Malaysia. Asia Pacific J Public Health. 2005; 17:130-6.

7. Niaura R. Nonpharmacologic therapy for smoking cessation: characteristics and efficacy of current approaches. Am J Med. 1992;121:511-9.

8. Kottke TE, Battista RN, DeFriese GH. Attributes of successful smoking cessation intervention in medical practice. A meta-analysis of 39 controlled trials. J Am Med Assoc. 1988;259:2883-9.

9. Balch GI, Tworek C, Barker DC, Sasso B, Mermelstein RJ, Giovino GA. Opportunities for youth smoking cessation: findings from a national focus group study. Nicotine and Tobacco Research. 2004;6:9-17.

10. Milton $\mathrm{MH}$, Maule CO, Backinger CL, Gregory DM. Recommendation and guidance for practice in youth tobacco cessation. American J Health Behavior. 2003;27:159-69.

11. Department of Selangor Education. ICT Unit Ministry of Education Malaysia. 2005.

12. Gilbert J. Botvin. Life skill training. Modified and translated by Drug Research Centre University Science Malaysia. 1979-1996.

13. Hashami B. The Effectiveness of health education package in smoking behavior modification. [thesis]. Kuala Lumpur. Universiti Kebangsaan Malaysia. 1998.

14. Ministry of Health Malaysia. Educational training module on preventing smoking, alcohol and drugs intake among teenagers. 2004. 
15. Corey G. Theory and practice of group counseling. $5^{\text {th }}$ ed. Brooks (USA). Cole Thomson Learning. 2000.

16. Hawe P, Degeling D, Hall J. Evaluating health promotion. Maclennan \& Petty Pty Limited, NSW Australia. 1992.

17. Schofield MJ, Lynagh M, Mishra G. Evaluation of health promoting school program to reduce smoking in Australian secondary schools. Health Education Res. 2003;18:678-92.
18. Bruvold WH. A meta-analysis of adolescent smoking prevention programs. Am J Public Health. 1993;83:872-80.

19. Frikart M, Etienne S, Cornuz J, Zelweger JP. Five day plan for smoking cessation using group behaviour therapy. Swiss Medical Weekly. 2003;133:39-43. 